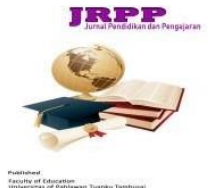

Muhammad Syahrul Rizal $^{1}$
Jurnal ReviewPendidikan dan Pengajaran http://journal.universitaspahlawan.ac.id/index.php/jrpp Volume 2 Nomor 2, Desember 2019 P-2655-710X e-ISSN 2655-6022
Submitted : 20/122019

Reviewed :23/12/2019

Accepted :25/12/2109

Published :28/12/2019

\title{
PENINGKATAN KEMAMPUAN MEMHACA PERMULAAN DENGAN MENGGUNAKAN METODE STRUKTURAL ANALITIK SINTETIK (SAS) TERHADAP SISWA KELAS I SDN 81 PEKANBARU
}

\begin{abstract}
Abstrak
Penelitian ini dilatarbelakangi oleh rendahnya tingkat kemampuan membaca permulaan siswa kelas I SDN 81 Pekanbaru. Salah satu solusi untuk mengatasi masalah ini adalah dengan menggunakan metode Struktural Analitik Sintetik. Tujuan penelitian ini untuk meningkatkan kemampuan membaca permulaan terhadap siswa SDN 81 Pekanbaru. Metode penelitian ini adalah Penelitian Tindakan Kelas (PTK) yang dilaksanakan dalam dua siklus, setiap siklus terdiri dari dua pertemuan dan empat tahap, yaitu perencanaan, pelaksanaan, observasi, dan refleksi. Waktu penenelitian ini dilaksanakan pada bulan Juni 2018. Sebagai subjek dalam penelitian ini adalah siswa kelas I tahun pelajaran 2017 - 2018 dengan jumlah siswa sebanyak 25 orang yang terdiri dari 12 siswa laki-laki dan 13 siswa perempuan. Teknik pengumpulan data yang digunakan dalam penelitian ini adalah teknik observasi, tes, dan dokumentasi. Berdasarkan hasil penelitian dapat disimpulkan bahwa sebelum tindakan siswa yang tuntas hanya15 orang siswa atau $60 \%$.Sedangkan pada siklus I meningka tmenjadi 18 orang siswa atau $72 \%$. Pada siklus II meningkat lagi hingga mencapai 23 orang siswa atau dengan persentase $92 \%$.Sehingga dapat disimpulkan bahwa dengan metode struktural analitik sintetik dapat meningkatkan kemampuan membaca permulaan siswa SDN 81 Pekanbaru.
\end{abstract}

\section{Kata Kunci: Metode Struktural Analitik Sintetik, Membaca Permulaan, Peningkatan Kemampuan}

\begin{abstract}
This research is backed by the low level of early reading ability of student grade I SDN 81 Pekanbaru. One solution to solve this problem is by using synthetic structural analytic methods.The purpose of this research is to improve the initial reading ability of students at SDN 81 Pekanbaru.This method of research is class action research conducted in two cycles, each cycle consists of two meetings and four stages, namely planning, implementation, observation, and reflection.This time of Weaver was held in June 2018. As a subject in this study was a class I year student from $2017-2018$ with a total of 25 students consisting of 12 male students and 13 female students. The data collection techniques used in this study are observation techniques, tests, and documentation.Based on the results of the study can be concluded that before the student's actions are completed only 15 the students or $60 \%$. As for the cycle I increased to 18 students or $72 \%$.In cycle II increased again to reach 23 students or with a percentage of $92 \%$. Thus, it can be concluded that with synthetic analytical structural methods can improve the ability to read the beginning of students SDN 81 Pekanbaru.
\end{abstract}

Keywords: Syntetik Analytical Structural Methods, Read To Beginning, The Ability

\footnotetext{
${ }^{1}$ Pendidikan Guru Sekolah Dasar, Fakultas Keguruan dan Ilmu Pendidikan, Universitas Pahlawan Tuanku Tambusai Alamat email syahrul.rizal92@gmail.com
} 


\section{PENDAHULUAN}

Pembelajaran Bahasa Indonesia merupakan pembelajaran yang diarahkan pada peningkatan kemampuan berkomunikasi siswa dalam bahasa Indonesia yang baik dan benar, baik secara lisan maupun tulisan, serta menumbuhkan apresiasi terhadap hasil karya kesastraan manusia Indonesia. Pelajaran bahasa Indonesia mencakup komponen kemampuan berbahasa dan kemampuan bersastra yang meliputi aspek mendengarkan, berbicara, membaca, dan menulis. Membaca merupakan suatu aktivitas yang dilakukan untuk mendapatkan sebuah informasi, memperoleh ilmu dan pengetahuan serta pengalaman pengalaman baru. Pada hakikatnya, aktivitas membaca terdiri dari dua bagian, yaitu membaca sebagai proses dan membaca sebagai produk. Membaca sebagai proses mengacu pada aktivitas fisik dan mental. Sedangkan membaca sebagai produk mengacu pada konsekuensi dari aktivitas yang dilakukan pada saat membaca ( Puji Santosa dkk, 2005: $6.3)$.

Kemampuan membaca tidak terlepas dari kemampuan membaca permulaan yang diajarkan di kelas satu dan dua. Menurut Tim Pembina Bimbingan Teknis Calistung (2013), membaca permulaan merupakan program pembelajaran yang diorientasikan kepada kemampuan membaca permulaan di kelas-kelas awal pada saat anak-anak mulai memasuki bangku sekolah. Pada tahap awal anak memasuki bangku sekolah di kelas I sekolah dasar, membaca permulaan merupakan menu utama. Menurut Resmini, dkk (2006:9) menjelaskan bahwa membaca permulaan pada intinya merupakan suatu upaya dari orang-orang dewasa untuk memberikan dan menerampilkan anak pada sejumlah pengetahuan dengan kemampuan khusus dalam rangka mengantarkan anak mencapai mampu membaca bahasa. Kemampuan membaca yang didapat dari membaca permulaan akan sangat berpengaruh terhadap kemampuan membaca lanjut. Sebagai kemampuan yang mendasari kemampuan berikutnya maka kemampuan membaca permulaan benar-benar harus diperhatikan guru sebagai tenaga pendidik. Sebab, jika dasar itu tidak kuat, pada tahap membaca lanjut siswa akan mengalami kesulitan untuk dapat memiliki keterampilan membaca yang memadai.

Untuk pembelajaran membaca permulaan, metode Struktural Analitik Sintetik (SAS) merupakan salah satu metode belajar yang dicoba diterapkan pada saat pembelajaran membaca permulaan. Metode SAS adalah suatu metode dengan media gambar yang di dalamnya terkandung unsur analitik sintetik. Menurut Tim Pembina Bimbingan Teknis Calistung (2013), metode membaca Struktural Analitik Sintetik atau yang biasa disingkat dengan metode membaca SAS merupakan salah satu metode yang dapat digunakan dalam pembelajaran membaca permulaan.

Dengan menggunakan metode SAS, siswa akan mengenal bagian kalimat sampai pada bagian terkecil dan siswa akan mengenal serta memahami sesuatu bacaan berdasarkan temuannya sendiri, sehingga pembelajaran akan lebih bermakna dan membantu siswa dalam keberhasilan belajar membaca permulaan. Hal ini akan memberikan dampak positif terhadap daya tangkap siswa dalam membaca permulaan serta memotivasi siswa yang malas membaca karena pembelajaran dibantu dengan media gambar.

Berdasarkan hasil observasi peneliti pada tanggal 10 maret 2018 teridentifikasi permasalahan yang menyebabkan rendahnya kemampuan membaca permulaan siswa yaitu Kurang tertariknya siswa dengan kegiatan membacapermulaan.,metode yang diterapkan oleh guru tidak bervariasi ,kebanyakan siswa yang sudah mengenal hurup masih lambat untuk merangkainya

Sehubungan dengan permasalahan tersebut ,maka peneliti tertarik melakukan perbaikan agar kemampuan membaca siswa kelas I dapat meningkat.Salah satu cara yang ditempuh oleh peneliti adalah dengan cara memilih salah satu metode pembelajaran yang bervariasi dan inovatif,sehingga dapat membuat proses pembelajaran yang menyenangkan baik untuk siswa maupun guru.Metode yang dipakai adalah metode struktural analitik sintetik (SAS).

Berdasarkan latarbelakang yang telah diuraikan di atas peneliti melakukan penelitian dengan judul "Peningkatan Kemampuan Membaca Permulaan dengan Menggunakan Metode Struktural Analitik Sintetik (SAS) terhadap Siswa Kelas I SD Negeri 81 Pekanbaru". 


\section{METODE}

Penelitian ini termasuk jenis penelitian tindakan kelas (PTK). Penelitian dimulai dari bulan mei 2018 minggu kedua sampai minggu pertama dibulan juni. Penelitian tindakan kelas ini dilaksanakan di SDN 81 Jalan Gabus no 6 Kota Pekanbaru. Subjek penelitian ini adalah siswa kelas I SDN 81 Pekanbaru.Dengan jumlah siswa 25 orang terdiri dari 13 siswa perempuan dan 12 siswa laki-laki

Variabel penelitian ini terdiri dari variable $\mathrm{X}$ (variabel bebas) yaitu metode struktural analitik sintetik (SAS) sedangkan variabel Y (variabel terikat) adalah kemampuan membaca permulaan dalam penelitian ini digunakan teknik pengumpulan data adalah data primer, yang maksudnya adalah data yang langsung diperoleh dari sumber utama penelitian. Teknik pengumpulan data primer ini dilakukan dengan cara teknik observasi dan teknik tes.

Analis data pada penelitian ini menggunakan data kuantitatif dan data kualitatif. Teknikanalisis kualitatif digunakan untuk mendeskripsikan proses pembelajaran dengan metode Struktural Analitik Sintetik ,yang terdiri dari aktivitas guru dan siswa selama proses pembelajaran dengan metode SASMenurut Miles dan Huberman ( dalam Sugiono 2009 :338 ) bahwa analisis data kualitatif adalah data yang dimulai dengan menelaah data sejak pengumpulan data sampai seluruh data terkumpul. Sedangkan data kuantitatif

Teknikanalisis kuantitatif digunakan untuk mengukur hasil belajar membaca permulaan siswa setelah penerapan metode struktural analitik sintetik. Analisa data dilakukan dengan melihat ketuntasan belajar siswa secara individual maupun klasikal Setiap siswa dikatakan tuntas belajarnya (ketuntasan individu) jika proporsi jawaban benar siswa $\geq 65 \%$ dan suatu kelas dikatakan tuntas belajarnya (ketuntasan klasikal) jika

dalam kelas tersebut terdapat $\geq 85 \%$ siswa yang telah tuntas belajarnya.( Depdikbud dalam Trianto,2010 241)

\section{HASIL DAN PEMBAHASAN}

Dari hasil pengamatan yang diperoleh saat pra tindakan, peneliti menyusun rencana pelaksanaan tindakan pada siklus I. Pelaksanaan tindakan pada siklus I dilaksanakan dengan 2 kali pertemuan. Pertemuan pertama dilaksanakan Senen tanggal 7 maret 2018, pertemuan kedua dilaksanakan Selasa tanggal 8 maret 2018. Tahap perencanaan atau persiapan tindakan, langkah - langkah yang akan dilakukan guru adalah sebagai berikut: menyusun sillabus mempersiapkan RPP siklus I, mempersiapkan kartu gambar sesuai dengan materi, .mempersiapkan bacaan sederhana sesuai metode SAS sesuai dengan gambar, menyiapkan lembar observasi aktivitas guru dan lembar observasi aktivitas siswa. Tindakan penelitian pada pertemuan I siklus I dilaksanakan pada hari senin tanggal 07 mei 2018. Indikator yang akan dicapai adalah siswa mengenal hurup dan dapat melafalkannya. Kegiatan awal dilaksanakan selama 10 menit. Kegiatan inti dilaksanakan selama \pm 45 menit, Pelaksanaan pembelajaran pada pertemuan 2 siklus I dilaksanakan pada hari selasa tanggal 8 mei 2018. Pokok bahasan masih tentang lingkungan dengan indikator siswa dapat menggabungkan hurup menjadi suku kata,kata dan kalimat sederhana serta dapat mengejanya dengan baik. Kegiatan awal \pm 10 menit dimulai dengan ketua kelas menyiapkan kelas dan siswa mengucapkan salam dan membaca doa bersama sama. Kegiatan inti dilaksanakan selama \pm 45 menit. Setelah melakukan tindakan maka guru memberikan tes kemampuan membaca permukaan kepada siswa. Adapun Hasil tes kemampuan membaca permulaan siswa siklus I dapat dilihat pada tabel 1 


\section{Hasil Tes Kemampuan Membaca Permulaan Siswa Kelas I SDN 81 Pekanbaru Pada Siklus I}

\begin{tabular}{|l|l|c|c|}
\hline \multirow{2}{*}{ No } & \multirow{2}{*}{ Interval (\%) } & \multicolumn{2}{c|}{ Siklus I } \\
\cline { 3 - 4 } & & $\mathrm{N}$ & $\%$ \\
\hline 1 & $85-100$ (Amat baik) & 7 & $12 \%$ \\
\hline 2 & $71-84$ ( Baik ) & 8 & $32 \%$ \\
\hline 3 & $65-70$ ( Cukup ) & 7 & $28 \%$ \\
\hline 4 & Kurang dari 65 (Kurang) & 25 & $100 \%$ \\
\hline JUMLAH SISWA & \multicolumn{2}{|c|}{70} \\
\hline \multicolumn{2}{|c|}{ RATA RATA } & 18 & \multicolumn{2}{|c|}{$72 \%$} \\
\hline KATEGORI & 7 & $28 \%$ \\
\hline \multicolumn{2}{|l|}{ JUMLAH YANG TUNTAS } & \multicolumn{3}{|c|}{28} \\
\hline \multicolumn{2}{|l|}{ JUMLAH YANG TIDAK TUNTAS }
\end{tabular}

Diketahui bahwa persentase ketuntasan siswa pada siklus I mencapai $72 \%$ atau 18 orang siswa yang tuntas. Persentase tidak tuntas adalah $28 \%$ atau 7 orang yang tidak tuntas. Kemudian rata-rata kemampuan membaca permulaan siswa pada siklus I mencapai $70 \%$ dengan kategori cukup. Walaupun kategori cukup namun ketuntasan siswa belum mencapai $75 \%$. Dari tabel tersebut menunjukkan bahwa kemampuan membaca permulaan siswa sudah tergolong cukup tetapi belum mencapai kriteria keberhasilan yang telah ditetapkan yaitu $\geq 75 \%$.

Setelah melihat perkembangan siswa pada siklus 1 maka dilanjutkan kesiklus II. Tahap perencanaan atau persiapan tindakan. langkah langkah yang akan dilakukan guru adalah sebagai berikut: menyusun sillabus ,mempersiapkan RPP siklus II, mempersiapkankan kartu gambar sesuai materi, mempersiapkan bacaan sederhana berdasarkan kartu gambar, mempersiapkan soal bacaan sederhana untuk test siklus II, menyiapkan lembar observasi aktivitas siswa dan lembar observasi aktivitas guru. Tindakan penelitian pada pertemuan I siklus II dilaksanakan pada hari senin tanggal 21 Mei 2018. Materi pembelajaran binatang kesayanganku dengan indikator membaca lancar suku kata,kata dan kalimat sederhana. Kegiatan awal dilaksanakan \pm 10 menit. Kegiatan inti dilaksanakan selama \pm 45 menit. Pelaksanaan pembelajaran pada pertemuan 2 siklus II dilaksanakan pada hari Selasa tanggal 22 mei 2018. Indikator yang akan dicapai membaca kalimat sederhana dengan intonasi yang benar. Kegiatan awal dilaksanakan \pm 10 menit. Kegiatan inti \pm 45 menit. Kegiatan akhir \pm 5 menit, guru mengulang bacaan dan menyimpulkan pelajaran untuk hari ini. kemudian guru memberikan bacaan untuk dibaca siswa dirumah. Setelah melakukan tindakan maka guru memberikan tes kemampuan membaca permukaan kepada siswa. Adapun Hasil tes kemampuan membaca permulaan siswa siklus II dapat dilihat pada tabel 2 


\section{Hasil Tes Kemampuan Membaca Permulaan Siswa kelas I SDN 81 Pekanbaru Pada Siklus II}

\begin{tabular}{|c|c|c|c|}
\hline \multirow{2}{*}{ No } & \multirow{2}{*}{ Interval (\%) } & \multicolumn{2}{|c|}{ Siklus II } \\
\cline { 2 - 4 } & & $\mathrm{N}$ & $\%$ \\
\hline 1 & $85-100$ (Amat baik) & 5 & $20 \%$ \\
\hline 2 & $71-84$ (Baik) & 8 & $32 \%$ \\
\hline 3 & $65-70$ (Cukup) & 10 & $40 \%$ \\
\hline 4 & Kurang dari 65 (Kurang) & 2 & $8 \%$ \\
\hline \multicolumn{2}{|c|}{ JUMLAH SISWA } & 25 & $100 \%$ \\
\hline \multicolumn{2}{|c|}{ RATA-RATA } & 23 & \multicolumn{2}{|c|}{ BAIK } \\
\hline \multicolumn{2}{|c|}{ JUMLAHEGORI } & 2 & $82 \%$ \\
\hline \multicolumn{2}{|c|}{ JUMLAH YANG TIDAK TUNTAS } \\
\hline
\end{tabular}

Berdasarkan tabel 4.7 diketahui bahwa persentase ketuntasan siswa pada siklus II mencapai $92 \%$ atau 23 orang yang tuntas. Persentase tidak tuntas $8 \%$ atau 2 orang siswa yang tidak tuntas. Rata - rata hasil belajar siswa pada siklus II mencapai 76,5 dengan kategori baik. Berdasarkan hasil yang diperoleh siswa pada siklus II, dapat disimpulkan bahwa keberhasilan membaca permulaan siswa kelas I SDN 81 Pekanbaru telah melebihi 75\%, yaitu dengan ketuntasan klasikal sebesar $92 \%$ dari 25 siswa. Sehingga penelitian ini hanya dilakukan sebanyak 2 siklus.

Sebagaimana diketahui bahwa pada siklus I kemampuan membaca permulaan siswa telah menunjukkan peningkatan dari sebelum tindakan, begitu juga pada siklus II meningkat dari siklus I. Peningkatan kemampuan membaca permulaan siswa dari sebelum tindakan hingga siklus II dapat dilihat pada tabel berikut.

\section{Peningkatan Kemampuan Membaca Permulaan Siswa Kelas I SDN 81 Pekanbaru Dari Sebelum Tindakan, Siklus I dan Siklus II}

\begin{tabular}{|l|l|l|l|}
\hline Keterangan & PraTindakan & Siklus I & Siklus II \\
\hline Siswa yang tuntas & $15(60 \%)$ & $18(72 \%)$ & $23(92 \%)$ \\
\hline Siswa yang tidak tuntas & $10(40 \%)$ & $7(28 \%)$ & $2(8 \%)$ \\
\hline
\end{tabular}

Berdasarkan tabel di atas, diketahui pada sebelum tindakan siswa yang tuntas hanya 15 orang siswa atau $60 \%$, yang tidak tuntas 10 orang siswa atau $40 \%$ dengan rata rata 63,17 .Sedangkan pada siklus I meningkat menjadi 18 orang siswa yang tuntas atau $72 \%$, yang tidak tuntas 7 orang atau $28 \%$ dengan rata - rata 70 . Pada siklus II diketahui bahwa siswa yang tuntas mencapai 23 orang siswa atau dengan persentase $92 \%$, yang tidak tuntas 2 orang atau $8 \%$ dan rata-rata hasil kemampuan membaca permulaan siswa siklus II adalah 76,5. Dengan demikian terdapat peningkatan ketrampilan membaca permulaan pada siswa SDN 81 Pekanbaru dengan menggunakan metode struktural analitik sintetik. 


\section{SIMPULAN}

Berdasarkan hasil analisis dan pembahasan seperti disampaikan pada hasil dan pembahasan dapat disimpulkan bahwa penerapan metode structural analitik sintetik dapat meningkatkan kemampuan membaca permulaan siswa SDN 81 Pekanbaru.Hal ini disebabkan adanya peningkatan baik aktivitas guru maupun aktivitas siswa dan seiring dengan menimgkatnya kemampuan membaca permulaan siswa dengan menggukan metode structural analitik sintetik mulai dari siklus I siswa yang tuntas 18 orang atau $72 \%$ dengan rata rata siswa 70.Pada siklus II meningkat menjadi 23 orang siswa yang tuntas atau $92 \%$ dengan rata rata siswa 76,5.

\section{DAFTAR PUSTAKA}

Abdurrahman, Mulyono. (2003). Pendidikan bagi anak berkesulitan belajar, Jakarta : PT.Rineke Arikunto, Suharsimi, dkk (2010), Penelitian Tindakan Kelas . Jakarta : Bumi Aksara

Puji Santoso, dkk (2005) . Materi dan pembelajaran Bahasa Indonesia . Jakarta : Universitas Terbuka..

Rahim, Farida . (2005). Pengajaran membaca disekolah dasar . Jakarta : Bumi Aksara.

Resmini , Novi . dkk 2006 a . Membaca dan Menulis di SD teori dan Pengajarannya . Bandung : UPI Press Tim Pembina Solchan, dkk.(2010) Pendidikan Bahasa Indonesia di SD . Jakarta : Universitas Terbuka.

Bimbingan Teknis CALISTUNG tingkat pusat (2013). Panduan Teknis Pembelajaran Membaca, Menulis. Dan Berhitung di Sekolah Dasar dalam Kemdikbud 2013

Zuchdi , Darmiyati , dkk . 1996/!997 . Pendidikan Bahasa dan Sastra Indonesia di KelasRendah . Jakarta : Departemen Pendidikan dan Kebudayaan.

Trianto (2010) Mendesain Model Pembelajaran Inovatif, Progresif, Konsep, LandasanDan Implementasinya pada Kurikulum Tingkat Satuan Pendidikan (KTSP)Jakarta : Kencana Prenada Media Group.

Syahrilfuddin, dkk .(2011). Penelitian Tindakan Kelas . Pekanbaru : Cendikia Insani

Emzir, (2007). Metodologi Penelitian Pendidikan Kuantitatif dan kualitatif . Jakarta :Pt. Raja Grafindo Persada

Sugiyono, (2009) . Metode Penelitian Kuantitatif, Kualitatif dan R\&D . Bandung :Alfabeta 